Journal of Animal and Veterinary Advances 18 (8): 246-250, 2019

ISSN: 1680-5593

(C) Medwell Journals, 2019

\title{
The Evaluation of Wafer Feed Supplement Containing Leucaena Leaf on Pasundan Calves
}

\author{
${ }^{1}$ Y. Retnani, ${ }^{1}$ S. Suharti, ${ }^{1}$ Taryati, ${ }^{2}$ Herni and ${ }^{1}$ D. Argadyasto \\ ${ }^{1}$ Department of Nutrition Science and Feed Technnolgy, Faculty of Animal Science, \\ Bogor Agicultural University, Jl. Agatis, Kampus IPB Darmaga, 16680 Bogor, Indonesia \\ ${ }^{2}$ Department of Nutrition and Feed Science, Graduate School of Bogor Agricultural University, \\ Bogor, Indonesia
}

\begin{abstract}
Livestock productivity required a variety of factors, one of which is the quality of feed. Limitation of livestock productivity in several area in Indonesia are low quality of feed, restricted of forage, especially, in dry seasson. A feed processing technology that might be addopted by to farmers the feed of wafers. Feed wafer processing technology is easy and cheap and can be used to treat these wastes into durable feed, easily to stored and easily given to livestock. Supplementation level in 5, 10 and $15 \%$ of wafer and without supplementation was observed in this research. The average daily weight gain by giving $10 \%$ of wafer feed supplement to pasundan calves is $58 \%$ most highest than other treatment. Final body weight of local calves by giving $10 \%$ of wafer supplement most higest than other treatment, the final body weight by giving $10 \%$ of wafer supplement around $14 \%$ higher than giving conventional feed only. Giving wafer feed supplements did not affect the physiological condition of the cattle based on haematology of blood.
\end{abstract}

$\underline{\text { Key words: Calves, growth, Leucaena sp. leaf, wafer feed supplement, livestock, physiological condition }}$

\section{INTRODUCTION}

Beef requirement in Indonesia continued to increase every year. Beef requirement continues to increase it was not in line with the local production for temporary solution by goverment is import. Beef import value in 2014 almost US\$ 700 million. To lower the value of imports started in 2016, beef imports began to be restricted, resulting in increased production of local beef encouraged to be improved.

As an example of the development of local livestock is pasundan cattle as a indigenous cattle in West Java. Pasundan cattle is a specified genetic resource from Indonesia that widely cultivated in buffer zone of teak forest in several district of West Java such as Ciamis, Pangandaran, Tasikmalaya, Cianjur, Sukabumi, Garut, Purwakarta, Kuningan and Majalengka. Pasundan cattles is able to live in poor quality of feed but can produce good quality of meat, resistant to heat stress can be applied to extensive breeding pattern and resistant to parasite (Anonymous, 2017a-c). Body size of pasundan cattle are shoulder height 115 in males and $109 \mathrm{~cm}$ in females. Body length of bulls an average 120 and $110 \mathrm{~cm}$ in females. Chest size bulls average 150 and $138 \mathrm{~cm}$ in females (Anonymous, 2017a-c). Pasundan cattle had been adaptive to weather and environtment conditions in West Java. With this potential, so that, it can be developed as livestock to fullfil the demand for beef, especially, in the region of West Java. To support livestock productivity, required a variety of factors, one of which is the quality of feed. In several area in Indonesia, to produce high quality of forage for cattle is not easy. In addition in dry season, quantity of forage descreased. This conditions causes the efforts to increase livestock production is difficult to achieve. The farmers in Indonesia not usual to collect and store while feed quantity is increase in rainy season. There has been no effort to collect and store forage in the rainy season for use as feed in the dry season. In the rainy season bring their animals to the land is overgrown with grass naturally, bind his livestock in these locations in some region the livestock may be moved outdoor during night, the livestock may be moved and only shifted his position if the grass is almost gone consumed by livestock.

One way to overcome the limitations of forage mainly by using alternative feed resources. As an example of using the leaves of Leucaena. In several area in Indonesia, Leucaena peas already consumed as food. So that, leaves of Leucaena not used for a human. Leucaena leaf can be used as a feed for livestock. But there is a should be considered in use Leucaena leaf is the content of antinutritive agent as a mimosine (Askar, 1997). Mimosine is non protein amino acid complex by a structure similar to tyrosine. Protein content of pea and

Corresponding Authore: Y. Retnani, Department of Nutrition Science and Feed Technnolgy, Faculty of Animal Science, Bogor Agicultural University, Jl. Agatis, Kampus IPB Darmaga, 16680 Bogor, Indonesia 
leaf of Leucaena are 34 and 31\%, respectively. Mimosine level containing in pea and leaf of Leucaena are more than $10 \%$ can decreased productivity of livestock (Sutardi, 1980). Previous research by the wafer feed supplement containing Leucaena leaf can decreased the mimosine level more than $30 \%$ and protein only for $0.6 \%$ (Argadyasto, 2015). So that, wafer feed supplement can be used as a supplement for livestock to optimalization of Leucaena leaf and increased livestock productivity.

Feed wafer processing is a technology using heat and pressure that could be disseminated to farmers is feed in the wafer form. Feed wafer processing technology is easy and inexpensive and can be used transform waste into an easy stored and distribute feed (Retnani et al., 2010). Feed wafers made using the aid of heat and pressure. Wafer is a material that has the dimensions (length, width and height) with a composition consisting of several fibers (Standard, 1994). Composition of product innovation of wafer is made to resemble the composition of the forage that is expected to be palatable and can be supplied with up to and overcome the scarcity of feed in the dry season.

In the previous research, supplementation of wafer containing Leucaena leaf for $10 \%$ can increased final body weight $28 \%$ more higer than conventional feed only using Bali calves (Retnani et al., 2014). In the other research for processing of Leucaena leaf as supplement in mash, pellet and wafer form, the best result for livestock performance used wafer form (Argadyasto, 2015). So that, the negative impact of mimosine to livestock can be minimize by using wafer form.

The aim of this research to assess the effect of wafer feed supplement containing Leucaena leaf on the production of pasundan calves.

\section{MATERIALS AND METHODS}

The 20 female calves used were distribute randomely create. The treatment abaout similar average weight. There to the the treatment were grouped in 5 categories very small, small, medium, large, very large. The research was conducted at Laboratory of Feed Industry, Faculty of Animal Science, Bogor Agricultural University and animal conducted on Cijeungjing, Ciamis Regency, West Java, Indonesia. The research started from September 2016 until December 2016. The 20 female a grouping based on body weight are very small, small, medium, large and very large with the age range of 6 months to 1 year. The average body weight in range $99 \pm 20 \mathrm{~kg}$ (Table 1).

Experimental design: The design used was a randomized block design with 4 treatments and 5 blocks as replication consisting of $\mathrm{T} 0=$ control (conventional feed), $\mathrm{T} 1=$ conventional feed $+5 \%$ wafer feed supplement, $\mathrm{T} 2$ = conventional feed $+10 \%$ wafer feed supplement and T3 = conventional feed $+15 \%$ wafer feed supplement. The variable that would be measured by:
Table 1: Nutrient content (\%Dry matter) of feed

\begin{tabular}{lcccc}
\hline Feed & Rice bran & Elephant & Rice straw & $\begin{array}{c}\text { Wafer feed } \\
\text { supplement }\end{array}$ \\
\hline Ash & 10.25 & 17.27 & 0.73 & 11.40 \\
Crude protein & 13.18 & 11.39 & 4.15 & 25.05 \\
Crude fat & 14.62 & 2.77 & 1.47 & 5.68 \\
Crude fiber & 10.41 & 27.52 & 32.50 & 9.86 \\
NFE & 48.45 & 58.96 & 44.98 & 51.99 \\
TDN & 73.79 & 49.70 & 43.20 & 71.12 \\
\hline
\end{tabular}

- In-vitro digestibility using Tilley and Terry methode

- $\quad$ Average Daily Gain (ADG)

Average daily gain (ghead/day) =

Final body weight gain (g)-Initial body weight (g) During this research (day)

- $\quad$ Blood haematology profile

Haemoglobin was used sahli tube methode and type of leukocytes observed directly under the microscope.

\section{RESULTS AND DISCUSSION}

In-vitro digestibility of wafer feed supplement: In this research, the wafer feed supplement the in-vitro Dry Matter Digestibility (DMD) and Organic Matter Digestibility (OMD) were 83 and 82\%, respectively. High digestibility reflect the contribution of nutrients in cattle while the feed have lower digestibility showed that the feed is less able to supply the basic nutrients for life and production (Rubianti et al., 2010). The DMD of the wafer containing Leucaena leaf was higher than founded by previous researcher who added Leucaena leaf meal up to 20-66\% (Haris, 2012). Digestibility of feed depends on the activity of ruminal microorganisms, rumen fermentation role in the process while the activity of ruminal microorganisms itself influenced by the nutrients in the feed (Crampton and Harris, 1969). Digestibility of organic material indicates the amount of protein, fat and carbohydrates that can be digested while the crude fiber is the limiting factor that will determine the level of the digestibility coefficient (Ter Meulen et al., 1979). The OMD of a wafer was $82 \%$. This shows that with the process feed processing can increase the organic matter digestibility.

The average concentrations of $\mathrm{NH}_{3}$ are high at $9.3 \mathrm{mM}$. The high concentrations of $\mathrm{NH}_{3}$ on a wafer feed supplements then pass to the post rumen organ will be low and the possibility of protein available to the animal itself is also low. In other feed processing, amino acids in the rumen will always form ammonia $\left(\mathrm{NH}_{3}\right)$. Ammonia is important for rumen microorganisms because as a major source of nitrogen and protein 
synthesized (Wartini, 2002). About $80 \%$ of the rumen microorganisms prefer ammonia over to peptide and amino (Baldwin and Allison, 1983). The concentration of ammonia in the rumen is a balance between the amount produced which is used by microorganisms and is absorbed by rumen. Various concentration of $\mathrm{NH}_{3}$ depending on the type of feed (Hungate, 1966).

Carbohydrates are the main energy source for livestock. Over $60-75 \%$ ruminant rations was eaten consist of carbohydrates (Sutardi, 1980). Carbohydrate fermentation in the rumen occurs in two steps. The first stage is the breakdown of complex carbohydrates into simple sugars, the next will be generated from simple Fatty Acids (VFA) which is the main energy source for ruminants (Owens and Bergen, 1983). Wafer feed supplement has a high VFA value is $164.55 \mathrm{mM}$.

Consumption of dry matter and protein: Table 2 based on the result of reserach showed that the treatment and block significant effect on dry matter intake of local calves $(\mathrm{p}<0.05)$. Ability of cattle to consume is very limited. Factors affecting feed intake in ruminants are given dietary factors, animal factors and environmental factors (Parakkasi, 1995). Dry matter consumption in this research was $2.3-2.8 \mathrm{~kg} / \mathrm{head} / \mathrm{day}$. The level of dry matter consumption of this study is higher than before research amounted to $1,2 \mathrm{~kg} /$ day in bali calves who received Leucaena supplements (Jelantik, 2001), even more higher than reported by other research is $1.1 \mathrm{~kg} /$ day bali cattle receiving supplemental feed solid starter with a $16.3 \%$ protein content. In this research indicates the wafer feed supplements can increased dry matter consumption. The supplementation $15 \%$ wafer feed supplement can increase dry matter consumption occurred compared with conventional feed about $19 \%$.

Nutrient requirement of cattle for weight $130 \mathrm{~kg} / \mathrm{head}$ are dry matter $3.9 \mathrm{~kg}$ with consist of protein 13.6 and TDN 64\% (NRC., 1996). In this study, protein consumption most higest in T3. Adequacy protein consumption in T3 about 13.3\% approched the NRC value. Treatment T3 is the most value for dry matter and protein consumption. This indicates giving higher of the wafer feed supplements can increasing consumption of local calves. Nutrient requirement are met will support the growth of calves in accordance with the genetic potential that the nutrient content and feed consumption has a great influence for growth (Soeparno, 2005).

Average daily gain and final body weight: Growth generally expressed with increasing body weight as a reflection of the nutrient adequacy consumption to the body's metabolism. Body weight gain is influenced by several factors such as the total consumption of protein obtained each day, gender, age, genetic, environmental,
Table 2: Consumption of dry matter and protein

\begin{tabular}{llllll}
\hline Consumption & & T0 & T1 & T2 & T3 \\
\hline Dry matter & g/head/day & $2261^{\mathrm{a}}$ & $2490^{\mathrm{b}}$ & $2597^{\mathrm{c}}$ & $2819^{\mathrm{d}}$ \\
Protein & g/head/day & $246^{\mathrm{a}}$ & $304^{\mathrm{b}}$ & $340^{\mathrm{c}}$ & $397^{\mathrm{d}}$ \\
\hline
\end{tabular}

*a-d Significant values

Table 3: Final body weight and average daily gain

\begin{tabular}{|c|c|c|c|c|}
\hline \multirow[b]{2}{*}{ Parameter } & \multicolumn{4}{|l|}{ Treatment } \\
\hline & T0 & $\mathrm{T} 1$ & $\mathrm{~T} 2$ & T3 \\
\hline $\begin{array}{l}\text { Initial body } \\
\text { weight }(\mathrm{X}) \text { (kg/head) }\end{array}$ & 103 & 102 & 98 & 97 \\
\hline $\begin{array}{l}\text { Final body } \\
\text { weight }(\mathrm{Y}) \text { (kg/head) }\end{array}$ & $125 \pm 18^{\mathrm{a}}$ & $138 \pm 23^{b}$ & $142 \pm 17^{b}$ & $132 \pm 25^{a b}$ \\
\hline$\triangle X Y(k g)$ & 22 & 36 & 45 & 35 \\
\hline $\begin{array}{l}\text { Percentage of } \\
\text { body weight } \\
\text { gain (\%) }\end{array}$ & 17,2 & 26,3 & 31,4 & 26,6 \\
\hline ADG (g/head/day) & $330 \pm 217^{\mathrm{a}}$ & $660 \pm 171^{\mathrm{b}}$ & $789 \pm 149^{c}$ & $608 \pm 124^{b}$ \\
\hline
\end{tabular}

physiological condition of the cattle and management. In general, the growth determined by measurements of weight and height (NRC., 1985). In addition to knowing the growth, measurement of body weight can determine the level of consumption, feed efficiency and price (Parakkasi, 1995) (Table 3).

The results showed that treatment of wafer feed supplements significantly in body weight gain $(p<0.05)$. The wafer feed supplements treatment had no significant effect ( $p>0.05$ ) on the block of final body weight. Final body weight gain in this study ranged 330-789 $\mathrm{g} /$ head/day. Giving of wafer in $10 \%$ level had Average Daily Gain (ADG) was higher than the other treatments. The wafer feed supplement was given to the local calves which has a weight of small, medium and large have the same response. Daily weight gain is influenced by several factors, namely the total consumption of protein, gender, age, genetic, environmental, physiological condition and management of livestock (NRC., 1985).

Body weight gain by giving of wafer feed supplement T1 (50\%), T2 (58\%), T3 (46\%) higher compared with conventional feed. While previous research daily weight gain of sumba ongol calves giving $15 \%$ of wafer feed supplements $42-45 \%$ higher compared to body weight daily by the conventional feed (Arief et al., 2016).

The results showed that treatment of wafer feed supplements significantly $(\mathrm{p}<0.05)$ in final body weight of bali calves during the research. The final body weight of calves with the wafer feed supplements at T1-T3 were 138,142 and $132.16 \mathrm{~kg} /$ head, respectively. Giving wafer feed supplements significantly $(p<0.05)$ increased the end of final body weight of local calves. Final body weight by giving $10 \%$ of wafer feed supplements $12 \%$ higher than conventional feed.

The results of ADG and final body weight, T3 not higher than T2, contrary with dry matter and protein consumption (Table 2). Dry matter and protein consumption of T3 was higher than the other treatment, 
especially, T2. This condition caused by limitting factor of mimosine content in Leucaena leaf. The Leucaena mimosine at a certain level in feed can caused loss of body weight of cattle. In treatment T2, mimosin level may still within the limits that can be tolerated by the animals. But in T3, mimosin level has exceeded the threshold of tolerance (Ghosh and Samiran, 2007).

In vivo digestibility: Measurement of the amount of undigested nutrients that can be done by knowing the dry matter and organic matter digestibility. Digestibility is the amount of feed that can be absorbed by the animal (McDonald et al., 2002). Value of digestibility of feed ingredients is an attempt to determine the amount of nutrients that feed material can be degraded and absorbed in the digestive tract of animals (Anggorodi, 1994). The value of dry matter and organic matter can indicated the degree of digestibility of a feed in the digestive tract of cattle and how much contribution a feed for livestock as well as an indicator of the ability of cattle to take advantage of a certain type of feed (Simanihuruk et al., 2006). Factors affecting the digestibility among other nutrient content of feed, feed composition, feed processing, feeding level and the factors of the animal itself. In Table 4 can be seen in dry matter, organic matter, protein and lipid digestibility showed no difference in treatment. Dry matter digestibility entire treatment is in the range $48-61 \%$. For organic matter digestibility in the range of $55-66 \%$. The digestibility was slightly lower than the type of cattle such as madura cattle with a dry matter of about 64-83\% (Arief et al., 2016). Sumba ongol calves by wafer feed supplement has a $74-76 \%$ dry matter and organic matter digestibility 76-78\% (Retnani et al., 2014) is higher than the digestibility of this research. Dry matter digestibility in cattle in the range of $50-75 \%$ (NRC., 2000).

Digestibility of protein in this study are in the range of $54-70 \%$, this result is also lower than studies with madura in the range of 74-89\% (Arief et al., 2016). Rough fat digestibility in this study are in the range of $80-85 \%$, fat digestibility in this study was higher than the digestibility of crude protein. The treatment has no effect on in vivo digestibility of calves weaning caused by many factors such as genetics and environmental conditions.

Blood haematology profile: Value hematocrit of calves in this study are in the range of $29.33-36.00 \%$. The value is still within the same range as those reported 28.14-30.32\% (Sattar and Mirza, 2009) and which is 25.89-36.01\% (Mirzadeh et al., 2010). Heat stress can lead to increased hematocrit value it is caused by the increased production of erythrocytes and a decrease in blood plasma (Santosa et al., 2012). In this study showed that cows pasundang in this study is not under stress that can reduce performance.
Haemoglobin levels in this study were in the range of $10.13-12.37 \mathrm{~g} / \mathrm{dL}$, this value is in the same range as those reported before which is about $9.95-11.81 \mathrm{~g} / \mathrm{dL}^{-1}$ (Sattar and Mirza, 2009) and also which is about 8.25-11.97 g/dL (Mirzadeh et al., 2010). Oxygen $\left(\mathrm{O}_{2}\right)$ requirements when cattle are stressed, so, the impact on the increase in hemoglobin. The conditions resulted in an increased rate of metabolism of the body during heat stress. In addition $\mathrm{O}_{2}$ levels were thin in the air as a result of the relatively high humidity can also increase the levels of hemoglobin in the blood (Santosa et al., 2012). This study did not show signs of an increase in hemoglobin. The number of leukocytes contained in the blood of local calves in this study is the range $11,100-13,167 / \mathrm{mL}$ by another research from 6.5-11.50 thousand/mL (Mirzadeh et al., 2010). In general, leukocytes does not indicated a problem (infection or inflammation) in the calves. This indicates that administration of wafer feed supplements did not affect the physiological condition of the calves weaning this indicates that the wafer feed supplements containing mimosin although not toxic.

\section{CONCLUSION}

Giving wafer 5, 10 and 15\% resulted in the average daily weight gain higher compared with conventional feed. The average daily weight gain by giving $10 \%$ of wafer feed supplements reached $789 \mathrm{~g} /$ head/day or $58 \%$ was higher than compared with conventional feeding only reached $330 \mathrm{~g} /$ head/day. Final body weight of local calves by giving $10 \%$ of wafer supplement reach the average 142 $\mathrm{kg} / \mathrm{head}$ higher than conventional feeding reaches the average final body weight $125 \mathrm{~kg} / \mathrm{head}$. Giving wafer feed supplements did not affect the physiological condition of the female calves.

\section{REFERENCES}

Anggorodi, R.R., 1994. Feed Science. PT Gramedia, Jakarta, Indonesia,.

Anonymous, 2017a. Decree of the minister of agriculture of the republic of Indonesia number. Ministry of Agriculture, Jakarta, Indonesia. (In Indonesian) http://disnak.jabarprov.go.id/files_arsip/Penetapan_ Rumpun_Sapi_Pasundan.pdf

Anonymous, 2017b. Pasundan cattle. Lembang Insemination Center, Lembang, Indonesia.

Anoymous, 2017c. Data based export-import for agricultural comodity in 2012-now. Ministry of Agriculture of Indonesia, Jakarta, Indonesia.

Argadyasto, D., Y. Retnani and D. Diapari, 2015. Processing of Leucaena leaf in physically form of mash, pellets and wafers as feed supplement for sheep. MSc Thesis, Bogor Agricultural University, Bogor, Indonesia. 
Arief, S., S. Suharti and L. Khotijah, 2016. Nutrient digestibility, rumen fermentation characteristic, nitrogen retention and performanceof beef cattle fed with ration containing soybean pod. D Pharm. Thesis, Bogor Agricultural University, Bogor, Indonesia.

Askar, S., 1997. Leucaena leaf nutritional value and utilization as ruminant feed. Livestock Research and Training Institute Sheikhupura, Sheikhupura.

Baldwin, R.L. and M.J. Allison, 1983. Rumen metabolism. J. Anim. Sci., 57: 461-477.

Crampton, E.W. and L.E. Harris, 1969. Applied Animal Nutrition: The use of Feedstuffs in the Formulation of Livestock Rations. W.H. Freeman, New York, USA., ISBN:9780716708148, Pages: 753.

Ghosh, M.K. and B. Samiran, 2007. Mimosine toxicity-a problem of Leucaena feeding in ruminants. Asian $\mathrm{J}$. Anim. Vet. Adv., 2: 63-73.

Haris, M., 2012. In vitro digestibility evaluation of Leucaena leucocephala as source of bypass protein with rice straw ammoniation based feed. Masters Thesis, Andalas University, Padang, Indonesia.

Hungate, R.E., 1966. The Rumen and its Microbe. 2nd Edn., Academic Press, Cambridge, Massachusetts, USA.,.

Jelantik, I.G.N., 2001. Improving Bali cattle (Bibos banteng wagner) production trough protein supplementation. Ph.D Thsis, Department of Animal Science and Animal Health, Bogor Agricultural University, Bogor, Indonesia.

McDonald, P., R.A. Edward, J.F.D. Greenhalgh, C.A. Morgan and L.A. Sinclair et al., 2002. Animal Nutrition. 7th Edn., Prentice Hall, Upper Saddle River, New Jersey, USA., Pages: 714.

Mirzadeh, K., S. Tabatabaei, M. Bojarpour and M. Mamoei, 2010. Comparative study of hematological parameters according strain, age, sex, physiological status and season in Iranian cattle. J. Anim. Vet. Adv., 9: 2123-2127.

NRC., 1985. Nutrient Requirement of Sheep. 6th Edn., National Academy Press, Washington DC, USA., Pages: 99.

NRC., 1996. Nutrient Requirement of Beef Cattle. 5th Edn., National Academy Press, Washington DC., USA.,.

NRC., 2000. Nutrient Requirements of Beef Cattle. 7th Edn., National Academies Press, Washington DC., USA., ISBN:9780309592413, Pages: 233.

Owens, F.N. and W.G. Bergen, 1983. Nitrogen metabolism of ruminant animals: Historical perspective, current understanding and future implications. J. Anim. Sci., 57: 498-518.
Parakkasi, A., 1995. Nutrition science of cattle. MSc Thesis, Department of Nutrition and Feed Technology, Bogor Agricultural University, Bogor, Indonesia.

Retnani, Y., C. Arman, S. Said, I.G. Permana and A. Saenab, 2014. Wafer as feed supplement stimulates the productivity of Bali calves. APCBEE. Procedia, 8: 173-177.

Retnani, Y., F.P. Syananta, L. Herawati, W. Widiarti and A. Saenab, 2010. Physical characteristic and palatability of market vegetable waste wafer for sheep. J. Anim. Prod., 12: 29-33.

Rubianti, A., P.T.H. Fernandez, H.M. Marawali and E. Budisantoso, 2010. Dry matter and organic matter digestibility of hay clitoria ternatea dan centocema poscourum CV cavalcadeon bali cattle post weaning. Proceedings of the International Seminar on Livestock and Veterinary Technology, August 3-4, 2010, Center for Research and Development of Animal Husbandry, Bogor, Indonesia, pp: 177-181.

Santosa, U., U.H. Tanuwiria, A. Yulianti and U. Suryadi, 2012. Utilization of organic chromium from leather tannery waste to reduce the stress of transport. JITV., 17: $132-141$.

Sattar, A. and R.H. Mirza, 2009. Haematological parameters in exotic cows during gestation and lactation under subtropical conditions. Pak. Vet. J., 29: 129-132.

Simanihuruk, K., K.G. Wiryawan and S.P. Ginting, 2006. [Effect of passion fruit peel (Passiflora edulis Sims F. Edulis Deg) as goat nut mixture: I. Nitrogen consumption, digestibility and retention (In Indonesian)]. JITV., 11: 97-105.

Soeparno, 2005. Science and Meat Technology. 4th Edn., Gadjah Mada University Press, Yokyakarta.

Standard, A.S.A.E., 1994. Wafers, Pellet and Crumbels-Definition and Methods for Determining Specific Weight, Durability and Moisture Content. In: Feed Manufacturing Technology, McEllhiney, R.R. (Eds.). American Feed Industry Association, Arlington, Virginia, pp: 527-527.

Sutardi T., 1980. Basic of nutrition science. MSc Thesis, Department of Nutrition and Feed Technology. Bogor Agricultural University, Bogor, Indonesia.

Ter Meulen, U., S. Struck, E. Schulke and E.A. El-Harith, 1979. A review on the nutritive value and toxic aspects of Leucaena leucocephala. Trop. Anim. Prod., 4: 113-126.

Wartini, E., 2002. Fermentability kinetics of Sauropus androgynus L. merr, Momordica charantia L. and Carica papa ya L. leaves in the rumen of cow. Msc Thesis, Bogor Agricultural University, Bogor, Indonesia. 